\title{
Analysis of significant learning in the flipped classroom: a conceptual cartography
}

\section{Análisis del aprendizaje significativo en el aula invertida: una cartografía conceptual}

\author{
ESCUDERO-NAHÓN, Alexandro†* \& MERCADO-LÓPEZ, Emma Patricia
}

Universidad Autónoma de Querétaro, Facultad de Infórmatica

ID $1^{\text {st }}$ Author: Alexandro, Escudero-Nahón / ORC ID: 0000-0001-8245-0838

ID $1^{\text {st }}$ Coauthor: Emma Patricia, Mercado-López / ORC ID: 0000-0003-0251-6783

DOI: $10.35429 / E J S .2020 .12 .7 .18 .27$

Received January 11, 2020; Accepted June 28, 2020

\begin{abstract}
The Flipped Classroom is an educational model that asks students to study educational content at home and come to the classroom for learning activities. This promotes meaningful learning with the help of digital technologies. The aim this documentary research was to analyze the relationship between the Flipped Classroom and learning meaningful, through Conceptual Cartography, in order to propose an evaluation model for Flipped Classroom. To achieve this, the documentary research method called Conceptual Cartography was applied, which is developed in four phases: The findings suggest that, theoretically, there is a direct relationship between the Flipped Classroom and meaningful learning. This relationship is based on the theoretical principles of constructivism. However, there are no specific instructional designs for the Flipped Classroom and, so far, the evaluation of the Flipped Classroom has focused on students' perception of the model and not on their significant learning. In conclusion, although the Flipped Classroom does easily admit constructivist theoretical foundations when promoting meaningful learning, this relationship has not been reflected in its own instructional designs, nor in properly constructivist evaluation models.
\end{abstract}

Flipped classroom, Learning significant, Conceptual cartography, Educative Technology

\begin{abstract}
Resumen
El Aula Invertida es un modelo educativo que solicita a los alumnos que estudien los contenidos educativos en casa y acudan al salón de clases a realizar actividades de aprendizaje. Así se promueve el aprendizaje significativo con ayuda de las tecnologías digitales. El objetivo de esta investigación documental fue analizar la relación que existe entre el Aula Invertida y el aprendizaje significativo, por medio de una Cartografía Conceptual, con el fin de proponer un modelo de evaluación para Aula Invertida. Para lograr lo anterior, se aplicó el método de investigación documental llamado Cartografía Conceptual. Los hallazgos sugieren que, teóricamente, sí existe una relación directa entre el Aula Invertida y el aprendizaje significativo. Esta relación se basa en los principios teóricos del constructivismo. Sin embargo, no existen diseños instruccionales propios para el Aula Invertida y, hasta ahora, la evaluación del Aula Invertida se ha enfocado en la percepción que tienen los alumnos sobre el modelo y no sobre su aprendizaje significativo. En conclusión, aunque el Aula Invertida sí admite con facilidad los fundamentos teóricos constructivistas al momento de promover el aprendizaje significativo, esta relación no se ha visto reflejada en diseños instruccionales propios, ni en modelos de evaluación propiamente constructivistas.
\end{abstract}

Aula invertida, Aprendizaje significativo, Cartografía conceptual, Tecnología educativa

Citation: ESCUDERO-NAHÓN, Alexandro \& MERCADO-LÓPEZ, Emma Patricia. Analysis of significant learning in the flipped classroom: a conceptual cartography. ECORFAN Journal-Spain. 2020. 7-12: 18-27.

\footnotetext{
* Correspondence to Author (Email: alexandro.escudero@uaq.mx)

$\dagger$ Researcher contributing first author.
} 


\section{Introduction}

The flipped classroom was created in 2007 by Jonathan Bergmann and Aaron Sams. These authors had two main objectives: to help students who were absent from class so that they did not fall behind in their academic performance, and to make the time of face-toface classes more efficient (López-Cobo, Nó, Martínez, \& Conde, 2018).

The flipped classroom is a new educational model that develops teachinglearning processes outside of class through Educational Technologies (ET). The goal is for students to study educational content at home and come to the classroom for dynamic learning activities, collaborative and discovery-based practices. In such a way that, theoretically, through ET and in favorable environments, the student collectively acquires, builds and consolidates knowledge and both he and the teachers evaluate learning (Barral, ArdiPastores, \& Simmons , 2018; Blau \& ShamirInbal, 2017).

The specialized literature on the flipped classroom admits that it is possible to adapt and integrate the constructivist theoretical foundations proposed by Piaget and Vygotsky. One of these foundations indicates that new knowledge is built on what the student previously knows. Therefore, in the flipped classroom, this principle is fulfilled when the student builds prior knowledge (from the elements with which he interacts, knows or reads outside of class) and new knowledge when attending the face-to-face class, with dynamic, practical and discovery-based learning activities (Barral et al., 2018; Blau \& Shamir-Inbal, 2017; Khahro, Javed, Pirzada, \& Ali, 2018; LópezCobo et al., 2018). Theoretically, the flipped classroom model is consistent with the educational principles of meaningful learning, which promote the construction of new knowledge from previous knowledge (Akçayır \& Akçayır, 2018; Lokse, Låg, Solberg, Andreassen, \& Stenersen, 2017).

It is relevant to remember that meaningful learning is a set of strategies aimed at the student learning to think-act, meaningfully, about the contents in a contextual way and, at the same time, know how to apply them appropriately in solving problems of everyday life (Díaz-Barriga \& Hernández, 2002, 2004; Lokse et al., 2017).
The specialized literature shows that there is empirical research on the perception that students have of the flipped classroom.

However, an exhaustive analysis of the relationship that exists between flipped classroom and significant learning has not been found. Therefore, there are no models for evaluating significant learning in the flipped classroom. It is necessary to carry out documentary and field studies to know if it is possible that the flipped classroom adapts the constructivist theoretical foundations, so that the students are able to obtain significant learning and can be evaluated under those same educational foundations.

\section{Aim and Method}

The general aim of this documentary research was to analyze the relationship between the flipped classroom and meaningful learning, through conceptual cartography, in order to propose an evaluation model for flipped classroom.

To comply with the above, the documentary research method called Conceptual Cartography was applied. Conceptual Cartography has the purpose of managing, building, relating knowledge in relation to a concept or theory. To meet the objectives of conceptual analysis, Conceptual Cartography follows a structure organized in four phases: 1) Search for specialized literature on the flipped classroom in scientific databases; 2) Definition of the inclusion and exclusion criteria of the documents; 3) Analysis of documents with seven categories (Notion, Characterization, Differentiation, Methodology, Evaluation, Exemplification, Advantages / Disadvantages); 4) Interpretation of the results (Tobón, 2012; Tobón, Guzmán, Silvano, \& Cardona, 2015).

\section{Phases of Conceptual Cartography}

The phases of Conceptual Cartography are as follows:

I) Search of specialized literature regarding the flipped classroom in scientific databases: a systematic search of research articles, books, and book chapters was carried out, in Spanish or English. Two scientific databases were used: Scopus and Science Direct. The search was performed between January and May 2019. 
II) Establishment of inclusion and exclusion criteria. The inclusion criteria were: a) The Boolean method was used with the terms: ("Flipped classroom" AND "Meaning learning"); b) Documents whose title, abstract or keywords included the aforementioned terms were considered; 3 ) Documents that had carried out empirical research in the field of education were admitted; 4) Documents in English and / or Spanish that were published between 2014 and 2018 were accepted. The exclusion criteria were: a) Documents whose focus was on distance education or virtual education; b) Scientific essays, book reviews, press releases and popular articles. In total, 51 records were obtained in total in both databases. Once the duplicate documents were discarded, a review of the relevance of each one was carried out and a total of 31 documents were admitted for analysis (Table 1).

\section{No. Author}

1 Aguilera-Ruiz, C., Manzano-León, A., Martínez-Moreno, I., Lozano-Segura, M., \& Casiano, C. (2017). El modelo de flipped classroom. International Journal of Developmental and Educational Psychology, 4(1), 261-266. https://doi.org/10.17060/ijodaep.2017.n1.v4.10 55

2 Akçayır, G., \& Akçayır, M. (2018). The flipped classroom: A review of its advantages and challenges. Computers \& Education, 126, 334345.

https://doi.org/10.1016/j.compedu.2018.07.021

3 Asarta, C., \& Schmidt, J. (2017). Comparing student performance in blended and traditional courses: Does prior academic achievement matter? The Internet and Higher Education, 32, 29-38.

https://doi.org/10.1016/j.iheduc.2016.08.002

4 Barral, A., Ardi-Pastores, V., \& Simmons, R. (2018). Student Learning in an Accelerated Introductory Biology Course Is Significantly Enhanced by a Flipped-Learning Environment. CBE-Life Sciences Education, 17(3), 1-9. https://doi.org/10.1187/cbe.17-07-0129

5 Being-Yi, C., Ching-Yi, C., Gwo-Haur, H., \& Fan-Ray, K. (2018). A situation-based flipped classroom to improving nursing staff performance in advanced cardiac life support training course. Interactive Learning Environments, 1-13. https://doi.org/10.1080/10494820.2018.148570 9

6 Blau, I., \& Shamir-Inbal, T. (2017). Re-designed flipped learning model in an academic course: The role of co-creation and co-regulation. Computers \& Education, 115, 69-81. https://doi.org/10.1016/j.compedu.2017.07.014

7 Domínguez, L., Sanabria, Á., \& Sierra, D. (2018). El clima productivo en cirugía: ¿una condición para el aprendizaje en el aula invertida? Educación Médica, 19, 263-269. https://doi.org/10.1016/j.edumed.2017.08.001
8 Gadbury-Amyot, C., Redford, G., \& Bohaty, B. (2017). Dental Students' Study Habits in Flipped/ Blended Classrooms and Their Association with Active Learning Practices. Journal of Dental Education, 81(12), 14301435. https://doi.org/10.21815/JDE.017.103

9 Hao, Y. (2016). Middle school students' flipped learning readiness in foreign language classrooms: Exploring its relationship with personal characteristics and individual circumstances. Computers in Human Behavior, 59 , 295-303. https://doi.org/10.1016/j.chb.2016.01.031

10 Hernández-Leo, D., \& Húnter, S. (2016). Towards integrated learning design with acrossspaces learning analytics: A flipped classroom example. En CEUR Workshop Proceedings (Vol. 1601, pp. 74-78)

11 Ibrahim, M., \& Izham, M. (2018). Chapter 3 Philosophy, Theories, Models, and Strategies in Pharmacy Education: An Overview. En Pharmacy Education in the Twenty First Century and Beyond (pp. 21-39). Doha Qatar: Academic Press. https://doi.org/10.1016/B9780-12-811909-9.00003-4

12 Kanayama, P., Santi, I., dos Santos, R., \& da Silva, L. (2018). Interdisciplinary active learning by an event of technology in English as an opportunity for empowerment and new possibilities. En International Symposium on Project Approaches in Engineering Education (Vol. 8, pp. 519-527). São Paulo, Brazil. Recuperado

https://www.scopus.com/record/display.uri?eid $=2-\mathrm{s} 2.0-$

$85054658598 \&$ origin $=$ inward $\&$ tx Gid $=f 37 \mathrm{~b} 7 \mathrm{ef}$ 56fbcfddb0f283fc6f1609076

13 Khahro, S., Javed, Y., Pirzada, N., \& Ali, T. (2018). Application of Flipped Class Room (FCR) and Task Based Approach (TBA) to improve Learning and Knowledge in Engineering Education. Journal of Engineering and Applied Sciences, 13(2), 388-393. https://doi.org/10.3923/jeasci.2018.388.393

14 Le Jeune, J. (2016). Flipped classroom: Didactic triangle meaning above below. Synergies Turquie, (9), 161-172. Recuperado de https://www.scopus.com/record/display.uri?eid $=2-\mathrm{s} 2.0$ -

$85014125554 \&$ origin $=$ inward \& $t x G i d=33121 \mathrm{~d} 0$ 594f8f42f66dceb58563dbc49

15 Lokse, M., Låg, T., Solberg, M., Andreassen, H., \& Stenersen, M. (2017). Chapter Six - Teaching It All. En Teaching Information Literacy in Higher Education (pp. 81-145). Chandos Publishing. https://doi.org/10.1016/B978-0-08100921-5.00006-0

16 López-Cobo, I., Nó, J., Martínez, E., \& Conde, J. (2018). Metodologías didácticas y recursos tecnológicos para el desarrollo del aprendizaje invertido. En CIIE Congreso Internacional de Innovación Educativa (pp. 984-988). Monterrey: Tecnológico de Monterrey.

17 Madrid, M., Angulo, J., Prieto, M., Fernández, M., \& Olivares, K. (2018). Implementación de aula invertida en un curso propedéutico de habilidad matemática en bachillerato. Revista Apertura, $10(1), \quad 24-39$. https://doi.org/10.18381/Ap.v10n1.1149 
18 Matzumura-Kasano, J., Gutiérrez-Crespo, H., Zamudio-Eslava, L., \& Zavala-Gonzales, J. (2018). Flipped Learning Model to Achieve Learning Goals in the Research Methodology Course in Undergraduate Students. Revista Electrónica Educare, 22(3), 1-21. https://doi.org/10.15359/ree.22-3.9

19 Melo, L., \& Sánchez, R. (2017). Análisis de las percepciones de los alumnos sobre la metodología aula invertida para la enseñanza de técnicas avanzadas en laboratorios de análisis de residuos de medicamentos veterinarios y contaminantes. Educación Química, 28(1), 3037. https://doi.org/10.1016/j.eq.2016.09.010

20 Muñoz, M., \& Vidal, M. (2018). Proyecto Aula invertida para el desarrollo de aprendizaje significativo en la educación postgradual en Salud. En Convención Internacional de Salud. Cuba.

21 Munir, M., Baroutian, S., Young, B., \& Carter, S. (2018). Flipped classroom with cooperative learning as a cornerstone. Education for Chemical Engineers, 23, 25-33. https://doi.org/10.1016/j.ece.2018.05.001

22 Nazarenko, A. (2015). Blended Learning vs Traditional Learning: What Works? (A Case Study Research). Procedia - Social and Behavioral Sciences, 200, 77-82. https://doi.org/10.1016/j.sbspro.2015.08.018

23 Pierce, L., \& Reuille, K. (2018). Instructorcreated activities to engage undergraduate nursing research students. Journal of Nursing Education, $\quad 57(3)$, 174-177. https://doi.org/10.3928/01484834-20180221-10

24 Putri, M., Rusdiana, D., \& Rochintaniawati, D. (2019). Students' conceptual understanding in modified flipped classroom approach: An experimental study in junior high school science learning. En I (Ed.), Journal of Physics: Conference Series (Vol. 1157, pp. 1-7). Indonesia: Institute of Physics Publishing. https://doi.org/10.1088/1742$6596 / 1157 / 2 / 022046$

25 Roach, T. (2014). Student perceptions toward flipped learning: New methods to increase interaction and active learning in economics. International Review of Economics Education, 17 ,

74-84. https://doi.org/10.1016/j.iree.2014.08.003

26 San-Valero, P., Robles, A., Ruano, M., Martí, N., Cháfer, A., \& Badia, J. (2018). Workshops of innovation in chemical engineering to train communication skills in science and technology. Education for Chemical Engineers, 26, 114121. https://doi.org/10.1016/j.ece.2018.07.001

27 Şengel, E. (2016). To FLIP or not to FLIP: Comparative case study in higher education in Turkey. Computers in Human Behavior, 64, 547-555. https://doi.org/10.1016/j.chb.2016.07.034

28 Smith, T., Rama, P., \& Helms, J. (2018). Teaching critical thinking in a GE class: A flipped model. Thinking Skills and Creativity, 28 , 73-83. https://doi.org/10.1016/j.tsc.2018.02.010

29 Sohrabi, B., \& Iraj, H. (2016). Implementing flipped classroom using digital media: A comparison of two demographically different groups perceptions. Computers in Human Behavior, 60, 514-524. https://doi.org/10.1016/j.chb.2016.02.056

\begin{tabular}{|c|l}
\hline 30 & $\begin{array}{l}\text { Wang, F. (2017). An exploration of online } \\
\text { behaviour engagement and achievement in }\end{array}$ \\
& flipped classroom supported by learning \\
& management system. Computers \& Education, \\
& 114, \\
& https://doi.org/10.1016/j.compedu.2017.06.012 \\
\hline 31 & $\begin{array}{l}\text { Webel, C., Sheffel, C., \& Conner, K. (2018). } \\
\text { Flipping instruction in a fifth grade class: A case } \\
\text { of an elementary mathematics specialist. } \\
\text { Teaching and Teacher Education, 71, 271-282. } \\
\text { https://doi.org/10.1016/j.tate.2018.01.007 }\end{array}$
\end{tabular}

Table 1 List of documents analyzed in the Conceptual Mapping

Source: own elaboration

III) Analysis of documents with seven categories. The analysis was performed according to the categories proposed by the Conceptual Cartography (Ortega-Carbajar, Hernández-Mosqueda, \& Tobón, 2015), but for the purposes of the investigation, the categories "Evaluation" and "AdvantagesDisadvantages" were incorporated. The categories of "Categorization", "Classification" and "Linking", which are proposed in the original Conceptual Cartography method, were discarded, because they did not present relevant results. The analysis was performed based on research questions (Tobón, 2012) (Table 2).

\begin{tabular}{|l|l|}
\hline \multicolumn{1}{|c|}{ Analysis category } & \multicolumn{1}{c|}{ Research question } \\
\hline 1. Notion & $\begin{array}{l}\text { What relationship exists } \\
\text { between the terms flipped } \\
\text { classroom and meaningful } \\
\text { learning? }\end{array}$ \\
\hline 2. Characterization & $\begin{array}{l}\text { What are the characteristics of } \\
\text { the flipped classroom related to } \\
\text { meaningful learning? }\end{array}$ \\
\hline 3. Differentiation & $\begin{array}{l}\text { From what models should the } \\
\text { flipped classroom be } \\
\text { distinguished and what role } \\
\text { does meaningful learning have? }\end{array}$ \\
\hline 4. Methodology & $\begin{array}{l}\text { With what methodology is the } \\
\text { flipped classroom carried out } \\
\text { and what role does meaningful } \\
\text { learning have? }\end{array}$ \\
\hline 5. Evaluation & $\begin{array}{l}\text { How is meaningful learning } \\
\text { evaluated in the flipped } \\
\text { classroom? }\end{array}$ \\
\hline 6. Exemplification & $\begin{array}{l}\text { At what levels or areas has the } \\
\text { flipped classroom been used to } \\
\text { foster meaningful learning? }\end{array}$ \\
\hline 7. Advantages- & $\begin{array}{l}\text { What advantages or } \\
\text { disadvantages has the flipped } \\
\text { classroom presented with } \\
\text { respect to meaningful learning? }\end{array}$ \\
\hline Disadvantages
\end{tabular}

Table 2 Categories of analysis and research questions Source: own elaboration based on Ortega-Carbajal et al., (2015)

IV) Interpretation of results. Once the research questions have been answered, the results are properly analyzed in section 3 . Results. 


\section{Results}

\section{Notion: What relationship exists between the terms flipped classroom and meaningful learning?}

The flipped classroom is an educational model where the student develops learning processes outside of class through ET. One of the objectives of the flipped classroom is to optimize the time allocated to face-to-face classes because the student previously studies at home and goes to the classroom to solve doubts and put into practice what has been learned with dynamic activities that promote discovery learning (Barral et al., 2018; Blau \& Shamir-Inbal, 2017; Matzumura-Kasano, Gutiérrez-Crespo, Zamudio-Eslava, \& Zavala-Gonzales, 2018; Melo \& Sánchez, 2017; Muñoz \& Vidal, 2018; Webel, Sheffel, \& Conner, 2018).

In developing this process, the flipped classroom integrates the student-centered constructivist theory (Akçayır \& Akçayır, 2018; Hao, 2016; Khahro et al., 2018; Lokse et al., 2017; Pierce \& Reuille, 2018; Putri, Rusdiana, \& Rochintaniawati, 2019) and, theoretically, this is how the learning strategies that promote meaningful learning are incorporated (Akçayır \& Akçayır, 2018; Blau \& Shamir-Inbal, 2017) (Figure 1).

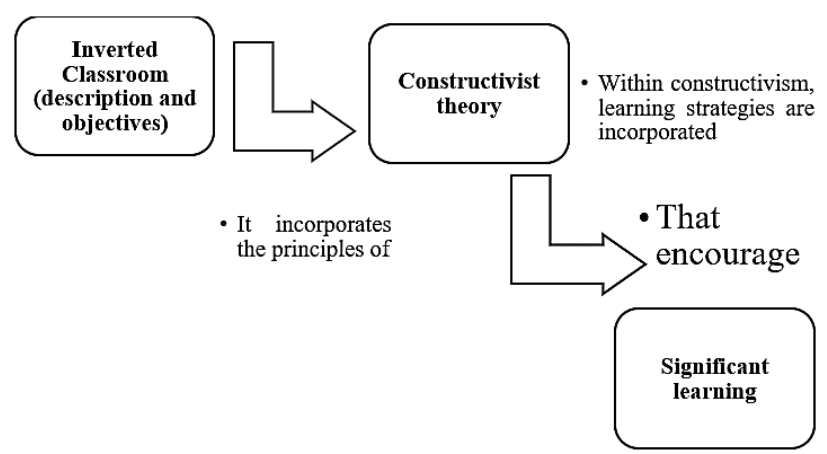

Figure 1 Relationship between the terms flipped classroom and significant learning

Source: own elaboration

The following learning strategies are commonly used in Constructivist Theory: 1) Active learning; 2) Self-regulated learning; 3) Cooperative and collaborative learning (Akçayır \& Akçayır, 2018; Blau \& Shamir-Inbal, 2017; Gadbury-Amyot, Redford, \& Bohaty, 2017; Kanayama, Santi, dos Santos, \& da Silva, 2018; Lokse et al., 2017; López-Cobo et al., 2018; Matzumura-Kasano et al., 2018; Melo \& Sánchez, 2017; Munir, Baroutian, Young, \& Carter, 2018); 4) Situated learning (Being-Yi, Ching-Yi, Gwo-Haur, \& Fan-Ray, 2018); 5) Problem-based learning (Khahro et al., 2018).
The reviewed scientific literature shows that all these learning strategies were used in the flipped classroom (Akçayır \& Akçayır, 2018; Being-Yi et al., 2018; Blau \& Shamir-Inbal, 2017; Gadbury-Amyot et al., 2017; Kanayama et al., 2018; Khahro et al., 2018; Lokse et al., 2017; López-Cobo et al., 2018; Matzumura-Kasano et al., 2018; Melo \& Sánchez, 2017; Munir et al., 2018).

Therefore, it is pertinent to mention that there is a direct relationship between the concepts flipped classroom, significant learning and Constructivist theory. From the theoretical, methodological and procedural points of view they are well harmonized.

\section{Characterization: What characteristics does the flipped classroom have related to meaningful learning?}

Some characteristics in the flipped classroom related to significant learning are (Figure 2):

a) The student builds his knowledge from the elements with which he interacts, knows or reads outside of class, before addressing the subject in the classroom. To interact with the topic, the student uses ET as support tools (Being-Yi et al., 2018; Blau \& ShamirInbal, 2017; López-Cobo et al., 2018; Matzumura-Kasano et al., 2018). Activities must be creative, based on the context and culture of the student, with the aim that they are meaningful (Being-Yi et al., 2018). In meaningful learning, meaning is attributed to new knowledge based on previous knowledge (Luna, 2014). Therefore, the acquisition of prior knowledge (with the help of ET) in the flipped classroom and anchoring with new knowledge contributes to significant learning in the flipped classroom.

b) The flipped classroom is centered on the student. Thus, students become part of their own learning process and thereby have meaningful learning (Melo \& Sánchez, 2017; Pierce \& Reuille, 2018; Roach, 2014).

c) Using ET as tools. Students learn outside the classroom with the help of ET and develop topics and content in an autonomous, creative and interactive way. According to constructivism, ET are strategic tools to promote meaningful learning (Being-Yi et al., 2018; Hernández-Leo \& Húnter, 2016; Ibrahim \& Izham, 2018; Kanayama et al., 2018; Madrid, Angulo , Prieto, Fernández, \& Olivares, 2018; Matzumura-Kasano et al., 2018; Melo \& Sánchez, 2017; Putri et al., 2019).

ESCUDERO-NAHÓN, Alexandro \& MERCADOLÓPEZ, Emma Patricia. Analysis of significant learning in the flipped classroom: a conceptual cartography. ECORFAN Journal-Spain. 2020 


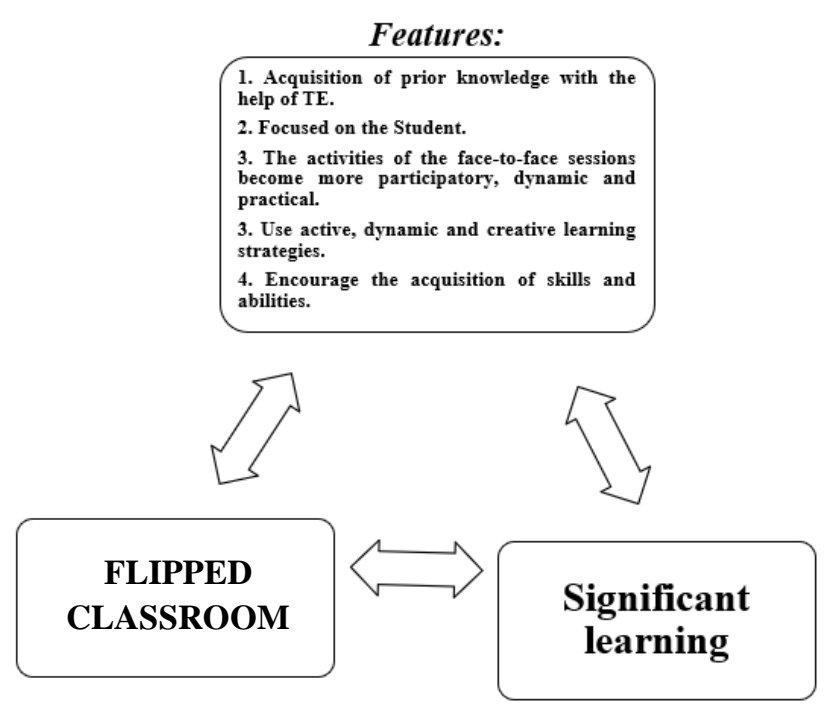

Figure 2 Relationship of the characteristics of the flipped classroom and significant learning Source: own elaboration

d) In the flipped classroom, the time allocated to face-to-face classes is used in dynamic and participatory activities, making the time more effective (Barral et al., 2018; Blau \& Shamir-Inbal, 2017). When students have active, participatory and dynamic classes, significant learning is fostered (Akçayır \& Akçayır, 2018; Being-Yi et al., 2018).

e) The flipped classroom uses learning strategies such as: A) Collaborative learning; B) Active learning; C) Selfregulated learning; D) Problem-based learning. Also, meaningful learning can be fostered with those same strategies. Some studies applied these strategies in the flipped classroom, but did not use an established model to assess whether significant learning was indeed generated (Akçayır \& Akçayır, 2018; Barral et al., 2018; Being-Yi et al., 2018; Kanayama et al., 2018; Lokse et al., 2017; Matzumura-Kasano et al., 2018).

f) Flipped classroom can promote critical thinking and problem solving skills, when appropriate strategies are used (active learning, collaborative learning, problembased learning) (Nazarenko, 2015; SanValero et al., 2018; Smith , Rama, \& Helms, 2018; Wang, 2017). As these competencies and skills are developed, meaningful learning can be promoted. However, in research carried out in the flipped classroom, only the perception that students have regarding their acquisition of competencies and skills was evaluated (Akçayır \& Akçayır, 2018; Blau \& ShamirInbal, 2017; Khahro et al., 2018; Lokse et al., 2017).

\section{Differentiation: From what models should the flipped classroom be differentiated and what role does meaningful learning have?}

The educational model of the flipped classroom is, properly speaking, a variant of the traditional model of education. Therefore, it is useful to list the differences between the traditional model of education and the flipped classroom. In the traditional model, the method is based on the teacher. The teacher transmits the knowledge to the students. The student receives the information passively from the teacher. The teacher evaluates. Learning is evaluated through standardized tests (Aguilera-Ruiz, ManzanoLeón, Martínez-Moreno, Lozano-Segura, \& Casiano, 2017; Asarta \& Schmidt, 2017; Barral et al., 2018; Lokse et al., 2017; López -Cobo et al., 2018; Munir et al., 2018; Nazarenko, 2015) (Table 3).

\begin{tabular}{|c|c|}
\hline Traditional model & Flipped classroom \\
\hline Focused on the teacher. & Focused on the student. \\
\hline $\begin{array}{ll}\text { Teacher } & \text { transmits } \\
\text { knowledge } & \text { and } \\
\text { it. }\end{array}$ & $\begin{array}{l}\text { Teacher guides, } \\
\text { facilitates, promotes, } \\
\text { advises, projects and } \\
\text { regulates knowledge. }\end{array}$ \\
\hline $\begin{array}{l}\text { The student's attitude is } \\
\text { individualistic. }\end{array}$ & $\begin{array}{l}\text { Teacher and student } \\
\text { evaluate. }\end{array}$ \\
\hline Does not require ET. & $\begin{array}{l}\text { A collaborative attitude is } \\
\text { encouraged. }\end{array}$ \\
\hline $\begin{array}{l}\text { Learning is assessed with } \\
\text { standardized tests. }\end{array}$ & Requires ET. \\
\hline $\begin{array}{l}\text { Teaching and assessment } \\
\text { are very different. }\end{array}$ & $\begin{array}{l}\text { Not only is learning } \\
\text { evaluated, but the } \\
\text { learning process. }\end{array}$ \\
\hline
\end{tabular}

Table 3 Differences between the Traditional Model of Education and the flipped classroom

Source: own elaboration

In general terms, the specialized scientific literature regarding the flipped classroom is very much about discourse on meaningful learning and constructivist theory. The same does not happen with the traditional educational model, which prioritizes the authority of the teacher and standardized and rote knowledge (Gadbury-Amyot et al., 2017; Lokse et al., 2017; Matzumura-Kasano et al., 2018; Melo \& Sánchez, 2017; Pierce \& Reuille, 2018).

Therefore, the flipped classroom would be an educational model where the theoretical principles of constructivism are more easily carried out.

Methodology: With what methodology is the flipped classroom carried out and what role does meaningful learning have?

The development in the flipped classroom is made up of four phases (López-Cobo et al., 2018):

ESCUDERO-NAHÓN, Alexandro \& MERCADOLÓPEZ, Emma Patricia. Analysis of significant learning in the flipped classroom: a conceptual cartography. ECORFAN Journal-Spain. 2020 
1) Experiential involvement (face-to-face time).

2) Exploration (non-contact time).

3) Creation of meaning (non-contact time).

4) Demonstration / application (face-to-face time) (Figure 3).

These phases allow acquiring skills and competences at higher levels. However, empirical research does not explain how these phases are carried out within an instructional design.

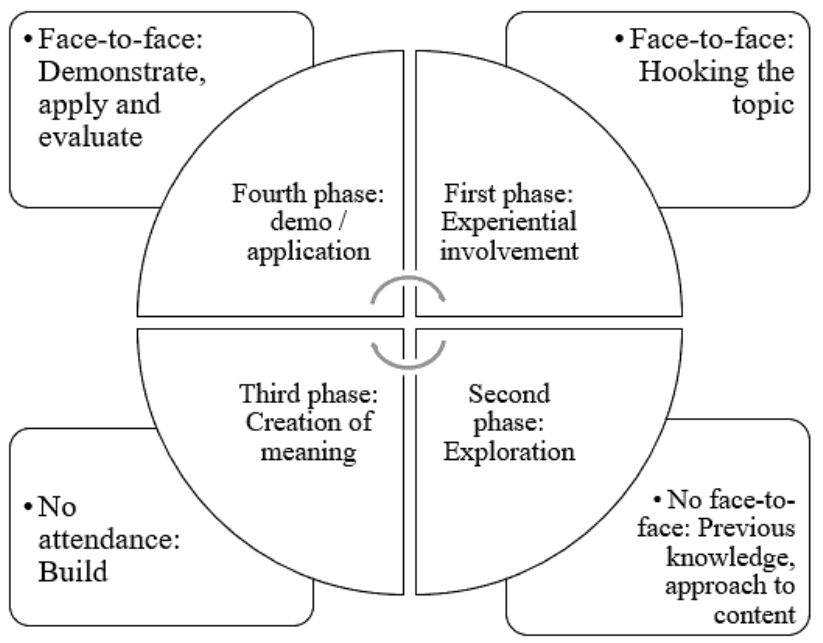

Figure 3 Phases of the flipped classroom

Source: own elaboration based on López-Cobo et al., (2018 p. 985)

Few documents give importance to instructional design within the flipped classroom (Ibrahim \& Izham, 2018; Jeune, 2016; Lokse et al., 2017; Roach, 2014). The above is relevant because an instructional design is a fundamental part when applying ET in a constructivist model, which plans, applies and evaluates activities to obtain meaningful learning. It is necessary to propose and evaluate instructional designs for the flipped classroom that integrate: 1) The phases in the flipped classroom; 2) The strategies and activities used based on the student-centered constructivist theory; 3 ) The competences and / or skills to be acquired; 4) The way to evaluate learning.

\section{Assessment: How is significant learning assessed in the flipped classroom?}

This Conceptual Cartography identified that there are no formal proposals for the evaluation of significant learning in the flipped classroom.

Until now, the evaluation in the flipped classroom is oriented to:

1) Analyze the perceptions that the Students have about this educational model.
2) Analyze the perceptions that students have about the application of some strategies in this educational model.

3) Identify the relationship between academic performance and this educational model.

However, a proposal for the evaluation of educational models that incorporate ET is currently being consolidated. The proposal is Learning Analytics and is proposed as a method of analyzing student learning behaviors in virtual educational models. Possibly, this proposal would have an adaptation to the flipped classroom, as long as there is previously a welldefined instructional design where algorithms capable of "tracking" the behavior of students on digital platforms can be built.

\section{Exemplification: At what levels or areas has the flipped classroom been used to foster meaningful learning?}

The application and research of the flipped classroom has increased in recent years (Akçayır \& Akçayır, 2018). The most addressed educational level is Higher Education, followed by Higher Secondary Education and, in very few cases, in Basic and Postgraduate Education. In the area of knowledge where the flipped classroom was used most frequently was in the Natural Sciences (Medicine, Nursing, Veterinary Medicine and Dentistry). Another area of knowledge less frequently was Mathematics (Engineering). Very few investigations report the area of Social Sciences. Research does not demonstrate whether there are procedural differences in the application of the flipped classroom at one level or another, or in one area or another.

However, there are several expert recommendations for conducting empirical research in different contexts and evaluating possible differences between different levels and areas.

\section{Advantages-Disadvantages: What advantages or disadvantages has the flipped classroom presented with respect to meaningful learning?}

The specialized literature indicates that the flipped classroom implies both advantages and disadvantages. The advantages shown are from the perception that the students have of the flipped classroom. The perception that students have is positive, in terms of improving participation, motivation and learning environment (Akçayır \& Akçayır, 2018; Domínguez, Sanabria, \& Sierra, 2018; Melo \& Sánchez, 2017).

ESCUDERO-NAHÓN, Alexandro \& MERCADOLÓPEZ, Emma Patricia. Analysis of significant learning in the flipped classroom: a conceptual cartography. ECORFAN Journal-Spain. 2020 
Other research explains (but does not demonstrate with evaluation tests) that the flipped classroom can promote: 1) Meaningful learning through some learning strategies (adaptive learning, active learning, collaborative learning); 2) Obtaining prior knowledge; 3) A profitability for private schools (this in economic terms) (Khahro et al., 2018; Lokse et al., 2017; Pierce \& Reuille, 2018).

Some important disadvantages mentioned are (Aguilera-Ruiz et al., 2017; Matzumura-Kasano et al., 2018):

1) There is no scientific database that explains, demonstrates, analyzes and evaluates the relationship between the flipped classroom and meaningful learning.

2) There is no instructional design with the constructivist characteristics that adapts to different contexts and with the phases in the flipped classroom.

Other disadvantages compared to the flipped classroom are not related to meaningful learning, but mainly to access to ET by students.

\section{Conclusions}

Through Conceptual Cartography it was established that:

I. Theoretically, there is a direct relationship between the flipped classroom and meaningful learning. This relationship is based on the theoretical principles of constructivism.

II. The flipped classroom is a booming educational model because it encourages students to study educational content at home with the use of ET and come to the classroom for dynamic, hands-on, discovery-based learning activities. In addition, in theory, this is how several precepts of the education that incorporates ET are fulfilled, such as the acquisition of digital competences, collaborative work because students can easily share digital information and, above all, meaningful learning because they face problems real of everyday life.
III. No instructional designs were found for the flipped classroom, demonstrating the integration of strategies for meaningful learning. Therefore, there is no proper instructional design for the flipped classroom, where the planning, application and evaluation of constructivist strategies is described. It is necessary to propose and evaluate instructional designs for the flipped classroom that integrate: 1) The phases in the flipped classroom; 2) The strategies and activities used in the constructivist theory; 3) The competences and / or skills to be acquired; 4) The way to evaluate learning.

IV. The phases in the flipped classroom have been poorly explained and evaluated within an instructional design.

V. In fact, up until now, the evaluation of the flipped classroom has been aimed at measuring the perception that students have about the model and not about their significant learning. Evaluation models should be proposed for the flipped classroom.

The lack of an instructional design and an evaluation model is relevant for the educational field because the lack of data regarding the suitability of using flipped classroom when promoting meaningful learning could lead to teacher disorientation and the subsequent frustration of students.

In conclusion, although the flipped classroom does easily admit constructivist theoretical foundations when promoting meaningful learning, this relationship has not been reflected in its own instructional designs or in properly constructivist evaluation models.

\section{References}

Aguilera-Ruiz, C., Manzano-León, A., Martínez-Moreno, I., Lozano-Segura, M., \& Casiano, C. (2017). El modelo de flipped classroom. International Journal of Developmental and Educational Psychology, 4(1), 261-266. https://doi.org/10.17060/ijodaep.2017.n1.v4.10 55

Akçayır, G., \& Akçayır, M. (2018). The flipped classroom: A review of its advantages and challenges. Computers \& Education, 126, 334345.

https://doi.org/10.1016/j.compedu.2018.07.021 
Asarta, C., \& Schmidt, J. (2017). Comparing student performance in blended and traditional courses: Does prior academic achievement matter? The Internet and Higher Education, 32, 29-38.

https://doi.org/10.1016/j.iheduc.2016.08.002

Barral, A., Ardi-Pastores, V., \& Simmons, R. (2018). Student Learning in an Accelerated Introductory Biology Course Is Significantly Enhanced by a Flipped-Learning Environment. CBE-Life Sciences Education, 17(3), 1-9. https://doi.org/10.1187/cbe.17-07-0129

Being-Yi, C., Ching-Yi, C., Gwo-Haur, H., \& Fan-Ray, K. (2018). A situation-based flipped classroom to improving nursing staff performance in advanced cardiac life support training course. Interactive Learning Environments, 1-13. https://doi.org/10.1080/10494820.2018.148570 9

Blau, I., \& Shamir-Inbal, T. (2017). Re-designed flipped learning model in an academic course: The role of co-creation and co-regulation. Computers \& Education, 115, 69-81. https://doi.org/10.1016/j.compedu.2017.07.014

Díaz-Barriga, F., \& Hernández, G. (2002). Constructivismo y evaluación psicoeducativa. En F. Díaz \& G. Hernández (Eds.), Estrategias docentes para un aprendizaje significativo: Una interpretación constructivista (pp. 349-425). México: McGraw-Hill.

Díaz-Barriga, F., \& Hernández, G. (2004). Estrategias docentes para un aprendizaje significativo (2a ed.). México: McGraw-Hill. Recuperado de http://formacion.sigeyucatan.gob.mx/formacion /materiales/4/4/d1/p1/2. estrategias-docentespara-un-aprendizaje-significativo.pdf

Domínguez, L., Sanabria, Á., \& Sierra, D. (2018). El clima productivo en cirugía: ¿una condición para el aprendizaje en el aula invertida? Educación Médica, 19, 263-269. https://doi.org/10.1016/j.edumed.2017.08.001

Gadbury-Amyot, C., Redford, G., \& Bohaty, B. (2017). Dental Students' Study Habits in Flipped/ Blended Classrooms and Their Association with Active Learning Practices. Journal of Dental Education, 81(12), 14301435. https://doi.org/10.21815/JDE.017.103
Hao, Y. (2016). Middle school students' flipped learning readiness in foreign language classrooms: Exploring its relationship with personal characteristics and individual circumstances. Computers in Human Behavior, 59 ,

https://doi.org/10.1016/j.chb.2016.01.031

Hernández-Leo, D., \& Húnter, S. (2016). Towards integrated learning design with acrossspaces learning analytics: A flipped classroom example. En CEUR Workshop Proceedings (Vol. 1601, pp. 74-78).

Ibrahim, M., \& Izham, M. (2018). Chapter 3 Philosophy, Theories, Models, and Strategies in Pharmacy Education: An Overview. En Pharmacy Education in the Twenty First Century and Beyond (pp. 21-39). Doha Qatar: Academic Press. https://doi.org/10.1016/B978-0-12811909-9.00003-4

Jeune, L. (2016). Flipped classroom: Didactic triangle meaning above below. Synergies Turquie, (9), 161-172. Recuperado de https://www.researchgate.net/publication/31668 5334_Flipped_classroom_Didactic_triangle_me aning_above_below

Kanayama, P., Santi, I. ., dos Santos, R., \& da Silva, L. (2018). Interdisciplinary active learning by an event of technology in english as an opportunity for empowerment and new possibilities. En International Symposium on Project Approaches in Engineering Education (Vol. 8, pp. 519-527). São Paulo, Brazil. Recuperado de https://www.scopus.com/record/display.uri?eid $=2$-s 2.0 -

85054658598\&origin $=$ inward\&txGid=f37b7ef5 6fbcfddb0f283fc6f1609076

Khahro, S., Javed, Y., Pirzada, N., \& Ali, T. (2018). Application of Flipped Class Room (FCR) and Task Based Approach (TBA) to improve Learning and Knowledge in Engineering Education. Journal of Engineering and Applied Sciences, 13(2), 388-393. https://doi.org/10.3923/jeasci.2018.388.393

Lokse, M., Låg, T., Solberg, M., Andreassen, H., \& Stenersen, M. (2017). Chapter Six - Teaching It All. En Teaching Information Literacy in Higher Education (pp. 81-145). Chandos Publishing. https://doi.org/10.1016/B978-0-08100921-5.00006-0 
López-Cobo, I., Nó, J., Martínez, E., \& Conde, J. (2018). Metodologías didácticas y recursos tecnológicos para el desarrollo del aprendizaje invertido. En CIIE Congreso Internacional de Innovación Educativa (pp. 984-988). Monterrey: Tecnológico de Monterrey.

Luna, V. (2014). Mapas conceptuales para favorecer el aprendizaje significativo en ciencias de la salud. Investigación en Educación Médica, 3(12), 220-223. https://doi.org/10.1016/S20075057(14)70940-8

Madrid, M., Angulo, J., Prieto, M., Fernández, M., \& Olivares, K. (2018). Implementación de aula invertida en un curso propedéutico de habilidad matemática en bachillerato. Revista Apertura, 10(1), 24-39. https://doi.org/10.18381/Ap.v10n1.1149

Matzumura-Kasano, J., Gutiérrez-Crespo, H., Zamudio-Eslava, L., \& Zavala-Gonzales, J. . (2018). Flipped Learning Model to Achieve Learning Goals in the Research Methodology Course in Undergraduate Students. Revista Electrónica Educare, 22(3), 1-21. https://doi.org/10.15359/ree.22-3.9

Melo, L., \& Sánchez, R. (2017). Análisis de las percepciones de los alumnos sobre la metodología aula invertida para la enseñanza de técnicas avanzadas en laboratorios de análisis de residuos de medicamentos veterinarios $\mathrm{y}$ contaminantes. Educación Química, 28(1), 3037. https://doi.org/10.1016/j.eq.2016.09.010

Munir, M. ., Baroutian, S., Young, B., \& Carter, S. (2018). Flipped classroom with cooperative learning as a cornerstone. Education for Chemical Engineers, 23, 25-33. https://doi.org/10.1016/j.ece.2018.05.001

Muñoz, M., \& Vidal, M. (2018). Proyecto Aula invertida para el desarrollo de aprendizaje significativo en la educación postgradual en Salud. En Convención Internacional de Salud. Cuba.

Nazarenko, A. (2015). Blended Learning vs Traditional Learning: What Works? (A Case Study Research). Procedia - Social and Behavioral Sciences, 200, 77-82. https://doi.org/10.1016/j.sbspro.2015.08.018

Ortega-Carbajar, M., Hernández-Mosqueda, J., \& Tobón, S. (2015). Análisis documental de la gestión del conocimiento mediante la cartográfia conceptual. Ra Ximal, 11(4), 141-160.
Pierce, L., \& Reuille, K. (2018). Instructorcreated activities to engage undergraduate nursing research students. Journal of Nursing Education, 57(3), 174-177. https://doi.org/10.3928/01484834-20180221-10

Putri, M., Rusdiana, D., \& Rochintaniawati, D. (2019). Students' conceptual understanding in modified flipped classroom approach: An experimental study in junior high school science learning. En I (Ed.), Journal of Physics: Conference Series (Vol. 1157, pp. 1-7). Indonesia: Institute of Physics Publishing. https://doi.org/10.1088/17426596/1157/2/022046

Roach, T. (2014). Student perceptions toward flipped learning: New methods to increase interaction and active learning in economics. International Review of Economics Education, 17 , https://doi.org/10.1016/j.iree.2014.08.003

San-Valero, P., Robles, A., Ruano, M., Martí, N., Cháfer, A., \& Badia, J. (2018). Workshops of innovation in chemical engineering to train communication skills in science and technology. Education for Chemical Engineers, 26, 114-121. https://doi.org/10.1016/j.ece.2018.07.001

Smith, T., Rama, P., \& Helms, J. (2018). Teaching critical thinking in a GE class: A flipped model. Thinking Skills and Creativity, 28 ,

https://doi.org/10.1016/j.tsc.2018.02.010

Tobón, S. (2012). Cartografía Conceptual: Estrategia para la formación y Evaluación de conceptos y teorías. Ciudad de México: CIFE.

Tobón, S., Guzmán, C., Silvano, J., \& Cardona, S. (2015). Sociedad del conocimiento: Estudio documental desde una perspectiva humanista y compleja. Paradigma, 36, 7-36. Recuperado de http://ve.scielo.org/scielo.php?script=sci_arttext \&pid=S1011-22512015000200002\&nrm=iso

Wang, F. (2017). An exploration of online behaviour engagement and achievement in flipped classroom supported by learning management system. Computers \& Education, 114 , 79-91. https://doi.org/10.1016/j.compedu.2017.06.012

Webel, C., Sheffel, C., \& Conner, K. (2018). Flipping instruction in a fifth grade class: A case of an elementary mathematics specialist. Teaching and Teacher Education, 71, 271-282. https://doi.org/10.1016/j.tate.2018.01.007 